\title{
Exercise of rights of tuberculosis patients undergoing pharmacological treatment
}

\author{
O exercício dos direitos das pessoas em tratamento farmacológico da tuberculose
}

El ejercicio de los derechos de las personas en tratamiento farmacológico por tuberculosis

\section{Bianca Contreira de Jung' \\ ORCID: 0000-0001-5947-1542 \\ Lisbeth Natalit Ampudia Tafur" \\ ORCID: 0000-0003-2789-0202 \\ Luize Barbosa Antunes" \\ ORCID: 0000-0003-3077-8609 \\ Giovana Calcagno Gomes ORCID: 0000-0002-2464-1537 \\ Roxana Isabel Cardozo Gonzales" ORCID: 0000-0001-7180-897X}

'Universidade Federal do Rio Grande. Rio Grande, Rio Grande do Sul, Brazil.

"Universidade Federal de Pelotas. Pelotas, Rio Grande do Sul, Brazil.

How to cite this article:

Jung BC, Tafur LNA, Antunes LB, Gomes GC, Gonzales RIC. Exercise of rights of tuberculosis patients undergoing pharmacological treatment. Rev Bras Enferm. 2020;73(Suppl 6):e20190631. doi: http://dx.doi.org/10.1590/0034-7167-2019-0631

Corresponding author: Bianca Contreira de Jung E-mail: bianca.jung@ucpel.edu.br

EDITOR IN CHIEF: Antonio José de Almeida Filho ASSOCIATE EDITOR: Ana Fátima Fernandes

Submission: 12-11-2019

Approval: 04-30-2020

\section{ABSTRACT}

Objectives: to know how people with tuberculosis undergoing treatment exercise their rights throughout daily life while experiencing illness. Methods: this qualitative study was developed from April to May 2015, with people with tuberculosis undergoing treatment in an outpatient clinic of the Municipal Tuberculosis Control Program in the city of Pelotas. Data were collected through semi-structured interviews and verified by content analysis, under the thematic modality. Results: people announced aspects that involved human rights pertaining to their experiences, and they had difficulties to achieve full rights to dignity, health, social security, and social services. Such rights were neither guaranteed by the State nor by their families. Final Considerations: it is necessary for health professionals and services to inform and equip people with tuberculosis, directly or indirectly, for the full exercise of their rights. Descriptors: Patient Rights; Tuberculosis; Nursing; Persons; Drug Therapy.

\section{RESUMO}

Objetivos: conhecer como pessoas em tratamento para tuberculose exercem seus direitos no cotidiano da experiência de adoecimento. Métodos: estudo qualitativo, desenvolvido de abril a maio de 2015, com pessoas em tratamento para a tuberculose em ambulatório do Programa Municipal de Controle da Tuberculose do município de Pelotas. Os dados foram coletados por meio de entrevistas semiestruturadas e verificados por análise de conteúdo, modalidade temática. Resultados: as pessoas anunciaram aspectos que envolveram os direitos humanos na vertente de suas experiências, tiveram dificuldades para obter direitos à dignidade, à saúde, previdenciários e sociais. Esses não foram garantidos pelo Estado e nem assegurados pela família. Considerações Finais: faz-se necessário que profissionais e serviços de saúde informem e instrumentalizem pessoas com tuberculose, direta ou indiretamente, para o exercício pleno de seus direitos.

Descritores: Direitos do Paciente; Tuberculose; Pessoas; Enfermagem; Tratamento Farmacológico.

\section{RESUMEN}

Objetivos: saber cómo las personas sometidas a tratamiento para la tuberculosis ejercen sus derechos en la experiencia diaria de la enfermedad. Métodos: estudio cualitativo, desarrollado de abril a mayo de 2015 , con personas que reciben tratamiento para la tuberculosis en una clínica ambulatoria del Programa Municipal de Control de la Tuberculosis en la cuidad de Pelotas. Los datos se recopilaron mediante entrevistas semiestructuradas y se verificaron mediante análisis de contenido, modalidad temática. Resultados: las personas anunciaron aspectos que involucraban los derechos humanos en términos de sus experiencias, tuvieron dificultades para obtener los derechos a la dignidad, la salud, la seguridad social y la seguridad social. Estos no estaban garantizados por el Estado ni por la familia. Consideraciones Finales: es necesario que los profesionales y servicios de salud informen e instruyan a las personas con tuberculosis, directa o indirectamente, para el pleno ejercicio de sus derechos. Descriptores: Derechos del Paciente; Tuberculosis; Personas; Enfermería; Tratamiento Farmacológico. 


\section{INTRODUCTION}

Tuberculosis (TB) is a reemerging disease in the global health context; even though it is preventable and curable, it remains the single agent infection that causes the highest number of deaths worldwide, eliminating more than 4,400 lives per day. Therefore, the World Health Organization (WHO) is concerned with ending the disease, considering it a public health problem ${ }^{(1)}$.

The growing AIDS epidemic, the increase in drug-resistant TB cases and the concentration of cases in vulnerable populations lead to prioritization of combating TB both globally and nationally. Data show that, in 2017, the world estimate indicated that 10 million people fell ill with TB and around 1.6 million died from the disease, with emphasis on Brazil, which is part of the 30 countries with the largest burden of this disease, ranking $19^{\text {th(1-2) }}$.

The Stop TB Strategy, proposed by WHO, aims to eliminate the epidemic by 2035, through United Nations actions based on the Sustainable Development Goals (SDGs). They include a $90 \%$ reduction in deaths from the disease by 2030. The SDG agenda promotes elimination of poverty, equity, justice, and human rights to provide better services to the most vulnerable populations ${ }^{(2)}$.

The Universal Declaration of Human Rights reaffirms that all basic rights must be guaranteed by the State. These rights are also guaranteed by the Brazilian Federal Constitution of 1988, which makes health a right for everyone and a duty of the State ${ }^{(3)}$. In this sense, the Brazilian National Tuberculosis Control Program (Programa Nacional de Controle da Tuberculose) uses national legislation to guarantee the population timely access to diagnosis and treatment, ensuring protection to the rights TB patients ${ }^{(4)}$.

The social vulnerability associated with TB signals to a population marked by needs that go beyond the illness itself. It involves living, working and housing conditions. In such a way, it is necessary to encourage these people to effectively exercise social control and other citizenship rights to participate in decision-making bodies of public policies ${ }^{(4-5)}$.

A qualitative study carried out in Pakistan, the $5^{\text {th }}$ country with the highest concentration of the disease in the world, has shown that there is still an information deficit about fundamental rights and this may create barriers to their effective exercise. Moreover, there were difficulties in ensuring the right to universal access to health services, privacy, free treatment, humanized care, work, and dignity ${ }^{(6)}$.

On the other hand, in France, a country with a low TB burden, it stands out that public health policies were articulated in order to provide early identification of TB cases and their contacts, thus granting effectiveness to the right to health. TB control centers reflect upon preservation of patient rights, confidentiality, ethics, and encourage them to exercise their own rights ${ }^{(7)}$.

The lack of information of TB patients regarding their health, social and information rights, among others, is something that is reproduced in different settings. Out of 34 National Tuberculosis Programs evaluated in Africa, only one indicated specific TB control policies, which indicated a lack of protection and guarantee of people's rights ${ }^{(8)}$.

Nursing care assists on the exercise of the right to health for people with TB, as nurses value preventive, educational, social and assistance dimensions in providing continuous and direct care. Thus, in daily care, nurses can support and show respect for patients' rights and advocate for them ${ }^{(9-10)}$.
Studies point out the leadership of nurses in care actions, since they are the professionals who most work with TB patients. In addition, they are a transformative, participatory and decisive agents in TB care actions, especially through health education, with guidance and clarifications about ensuring rights ${ }^{(11-14)}$.

Therefore, this research intends to point out the importance of knowledge by TB patients about the full exercise of their rights, and its influence for compliance with treatment and cure. Furthermore, health/nursing services and professionals are participants in this process, in which informing, guiding, clarifying, and empowering the population is fundamental to transform the TB situation and make these people's lives more dignified.

\section{OBJECTIVES}

To know how people with TB undergoing treatment exercise their rights throughout daily life while experiencing illness.

\section{METHODS}

\section{Ethical aspects}

The Research Ethics Committee of the Faculty of Medicine of Universidade Federal de Pelotas approved this study under Protocol 968.466/2015 and CAEE (Certificado de Apresentação para Apreciação Ética - Certificate of Presentation for Ethical Consideration) 41851315.4.0000.5317, according to Resolution 466/2012. Participants signed the Informed Consent Term and had their anonymity guaranteed by the use of fictitious names.

\section{Theoretical-methodological framework and type of study}

This article is the product of a Brazilian dissertation entitled "Os significados da experiência do adoecimento de pessoas com tuberculose $e^{\prime \prime(15)}$. This qualitative and descriptive study was based on understanding the meanings of these illness experiences. The theoretical framework in use contemplated the perspective of health anthropology, aiming to understand the meanings of the illness experience through the body, which is the creative agent and the producer of the experience. It is understood that the state of illness (in its process), experienced through the body, does not belong to separate worlds (physical-emotional), as the disease is present in the vital world, so understood as everything that involves people's lives and that is essential for them ${ }^{(16)}$.

\section{Type of study}

This descriptive study, with a qualitative approach, is guided by the Consolidated Criteria for Reporting Qualitative Research (COREQ), Equator instrument.

\section{Methodological procedures}

\section{Study setting}

The outpatient clinic of the Municipal Tuberculosis Control Program (Programa Municipal de Controle da Tuberculose) of the city of Pelotas, in the state of Rio Grande do Sul, was elected as the 
study location, since it is a reference center in the care of people with TB in the 22 cities of the $3^{\text {rd }}$ Regional Health Coordination. Pelotas is one of the 20 cities in the state with the highest number of cases, with 204 cases of pulmonary TB and an incidence coefficient of 48.2 per 100-thousand inhabitants ${ }^{(17)}$.

In this service, the researcher performed an acquaintance experience to meet the people in treatment, in which she was able to establish a relationship with the participants before the beginning of the study. She highlighted her personal goals and reasons for carrying out her Master's research, in addition to the importance of their contribution to study completion.

\section{Data source}

Ten people with pulmonary TB, undergoing treatment at the outpatient clinic, participated in the study. They were elected according to the following inclusion criteria: adults of both sexes, diagnosed with pulmonary $\mathrm{TB}$, in the second phase of treatment; based on the understanding that, in the fourth month of treatment, people would possibly have gathered more information about their experiences of illness. The clinic provided a data sheet that contained 23 people being treated for TB. Out of them, five were part of the pilot test, five had the extrapulmonary form of the disease, and three refused to participate on grounds of a lack of interest. People with any kind of speech disorder that could prevent communication and people under institutionalization (Long Term Care Institutions, prisons and hospitals) were excluded. Participants were recruited individually by telephone for the invitation to participate in the research and to schedule the interview, according to their acceptance and availability in relation to the day, time and place.

\section{Data collection and organization}

The main researcher at the time, a master's student in science, conducted only the interviews, based on a semi-structured script, with questions that sought to understand the experiences of illness: what was it like to be sick with TB? Regarding the health service, where did you receive treatment? How was your treatment for TB? How was the issue of your family since you became ill? The interview guide was tested to validate the understanding of the questions with five people who did not compose the final sample. Before the start of data collection, the interviewer commented on being a nurse, her federal teaching institution and her supervisor, in addition to explaining the consent term, with regard to the research objective and the adopted procedures, which would not present physical risks. She also informed that there could be emotional discomfort during the interviews and that, therefore, they could give up participating at any time, as well as explaining benefits, voluntary participation and confidentiality.

The interviews were conducted between April and May 2015, in the participants' homes, where there were other family members in different rooms of the house, with an average duration of 40 minutes and recorded with an audio device. One of the interviews had to be repeated since the participant started coughing intermitently and asked to have the interview postponed. Fieldwork reports were made during and after each interview.

\section{Data analysis}

Study data were analyzed using the thematic content analysis technique, comprising the pre-analysis phase, material exploration and result treatment ${ }^{(18)}$. In the first phase, a general reading of all interviews was performed, then the transcription of data, which was not returned to the participants for comments or corrections. That progressed into systematizing the ideas from the collected information, building the corpus of analysis.

In the material exploration phase, coding operations were constructed, considering the excerpts from the interview texts under the following record units: illness, TB, perception, health, rights to diagnosis and treatment. From these identified units originate the category and subcategories of analysis: "The experience of people with TB in the exercise of their rights" is the category, subdivided into "Human Rights", "Right to dignity, freedom, honor and respect", "Economic and Social Rights", "Right tomedical leave from work", "Right to Social Security", "Rights in the prison system" and "Right to health". In the third phase, the manifest and latent contents contained in all interviews were captured, and the participants did not provide feedback on the results.

\section{RESULTS}

Regarding the sociodemographic data of the ten participants, six were men and four women, who were between 25 and 52 years old. Low educational level predominated in the sample, as seven people had incomplete elementary school education and three had incomplete high school education. Eight participants had minimum wage income monthly, and two earned more than one minimum salary monthly. General services were the kind of labor six of the participants worked with, whereas four of them were homemakers.

\section{Human Rights}

The people in this research, through their experiences of living with $\mathrm{TB}$, announce that human rights were not fully guaranteed in dignity conditions and in the value of human beings. These rights were not guaranteed or presented vulnerabilities regarding the protection of dignity of the human person in all of its dimensions, felt by physical and emotional transformations.

Most of the people who have treated me know nothing about tuberculosis. Mainly in the hospital [Hemodialysis Unit] because of the disrespect. When they discovered that I had tuberculosis, they did not even come to talk. They are misinformed about what tuberculosis is. I felt very harmed. Inside the hospital, they still treat the disease like a seven-headed beast. (Laureano)

It is a disease that is complicated and that I don't like to be talking to others about, because they think that even talking to you, they will catch it. I didn't even get close to my daughter, I'm afraid. (Mauro)

I was a little disturbed by that disease, because I didn't expect it. I was upset and surprised. The person feels that way, I don't know, it seems that he is isolated. Will I recover or not? (Maiara) 


\section{Right to dignity, freedom, honor, and respect}

The fact that they are sick with a disease that has deep-rooted historical and cultural mystification causes people with TB to leave family life, as they suffer rejection and there is fear of contagion. Faced with this social discrimination linked to their own family members, their right to live with Dignity, Freedom, Honor and Respect in their human and social condition was not guaranteed even by their families, which should be a source of support and protection:

I didn't know it was so bad, because I didn't adapt either to the drugs nor to anything. I suffered prejudice from my own family. It was very difficult for me to discover tuberculosis. (Juliana)

There is an uncle of mine who left because I got tuberculosis, he came over to see my grandmother often and then he didn't come over again. (Mateus)

I was depressed by people's rejection, it hurts, I even cried at first. I suffered this prejudice, it came from my husband's uncle, before I knew it was tuberculosis, he was always supporting me, he said he was going to pray for me, but when he found out it was tuberculosis, he turned his back on me, disappeared. (Juliana)

My family was terrified because I got this disease; they separated the cutlery and these things in order not to get infected. (Jeremiah)

Once in a while, I was upset because I like children and my sister told the children to go to another room at home. At first, I was upset because nobody came near me because I was sick. (Maiara)

\section{Economic and social rights}

Luis Ricardo felt that the illness due to TB further aggravated his financial difficulty, because he had already been in a situation of vulnerability and social risk before. Thus, economic and social rights, related to their disadvantaged living conditions, were not brought to effectiveness by the State, being heavily struck down before and after living with the disease.

We have difficulties in the financial area and we had already had some difficulties before. My family has difficulties in the financial area because I haven't been not working. I have no spirit, that willpower to work and my wife also has no steady job, she is a person who studied very little too. (Luis Ricardo)

\section{Right to medical leave from work}

The experience of illness for Maiara and Cleusa revealed the exercise of the right to leave work due to contracting a disease that weakens one's physical and emotional condition, which may result in temporary and even permanent damage. In Maiara's work environment, it was noticed she had signs of TB, so she was oriented to move away from the workplace and seek care; while Cleusa herself recognized and exercised the right to leave work due to poor health.

The disease got worse and I got sick, looking for a job while feeling sick. I worked twice while ill and kept holding on to everything I could. I was going to wait until February before I could have an $x$-ray, but as the foreman realized I was really bad, I had a dry cough, my stomach hurt, it felt like I was going to lose my breath, he told me to leave the firm and go to the doctor. I had an appointment and it was found that I had tuberculosis. (Maiara)

Immediately I stopped working and I couldn't take it anymore. Then, I started the treatment and stayed away from the job because it is our right. (Cleusa)

\section{Right to Social Security}

Specifically for people with active TB such as Luis Ricardo, the following social security benefits stand out: sickness benefit and disability retirement. Due to their illness and inability to work, the participant exercised his/her right to sickness benefit, but this benefit was not granted by the social security office.

I went to the Brazilian National Social Security Institute [INSS Instituto Nacional do Seguro Social] and my expert examination was denied. I tried to get the sickness benefit, the doctor there at the examination denied it, she didn't give it to me. She said I didn't need the sick benefit. The financial situation got worse and we are taking it as we can. (Luis Ricardo)

\section{Rights in the prison system}

For Marcelo, the experience of illness involved being deprived of liberty and not having the fundamental right to health guaranteed by the State regarding early diagnosis and treatment. Marcelo used to be part of one of the populations who are considered most vulnerable and most likely to have TB, therefore, who should be investigated periodically for early identification of the disease and initiation of immediate treatment.

Because I didn't realize I had tuberculosis out on the street, at the time I was in prison, but the health service there took a long time. It took them 15 days to be able to give me some certainty, only then I started taking the medicine. They didn't give me medicine at first, it took a long time. (Marcelo)

\section{Right to health}

Health is a fundamental right of the human being, and the State must provide the conditions indispensible for its full exercise. However, Maiara's, Juliana's and Julia's illness experiences show the lack of effectiveness of this right, especially with difficulties in universal and egalitarian access to actions and services for early diagnosis.

Within three weeks, I went to the health clinic. The third time, the doctor was terrified to see my lungs, she said it looked like a popped balloon, that they had a lot of phlegm. I don't wish this on anyone, because it's horrible, you can't sleep at night and often think you won't wake up, it's horrible. (Maiara)

In October, I had the flu and I went to the doctor at the clinic nearby, but the doctor does not examine you, does not listen to you and does nothing, it seems that the doctor is disgusted to touch you. I told her and she said that I was feeling this way due to the change in the weather, she gave me some syrup, I took the 
syrup and I felt it didn't have much effect. The doctor herself said it was nothing, it was a change in the weather. In October, the disease came with everything. To know what it was, it took me almost a month. (Juliana)

They were treating me like it was an infection, an infection that grew in the lung and was not tuberculosis. (Julia)

The rights announced through the illness experience should guarantee people a dignified life, however, the matertial unavailability of these rights was unveiled. Human, social, economic, health and social security rights, mentioned in this research, would contribute to improving living conditions especially for the most disadvantaged people, so that citizenship, dignity and social equality - the foundations of the Brazilian Democratic State - could be achieved.

\section{DISCUSSION}

There is an urgent need to guarantee the rights of people with $T B$, rights that constitute a fundamental and inalienable pillar of the health sector response facing this disease. TB affects vulnerable population groups and the principles of human rights are the basis for ensuring human dignity, starting with the right to life, and forging on to the rights to freedom, equality, health, education, well-being, labor, as well as the full development of personality ${ }^{(19-2)}$.

In this sense, the illness experiences of most of the participants were marked by a State that did not provide the necessary conditions to fully ensure the right to health, given the difficulties of access to rapid diagnosis and treatment. An article that discusses the challenges to eliminate TB in Brazil points to the need for integrated approaches to detect and treat active disease, and the requirement that governments take responsibility for ensuring universal access to health services ${ }^{(21)}$.

The first step towards TB control is the early identification of people with the disease, in order to guarantee the right to timely diagnosis and treatment, which was not fully ensured to the participants of this study. Thus, research involving the theme of health rights revealed difficulty in access to services, people's dissatisfaction with the care provided by health teams, lack of information about the disease and treatment, and lack of free medicine ${ }^{(6,22)}$.

With the illness experiences, it was also possible to perceive the difficulties that people presented due to their situations of vulnerability, which influence the process of falling ill. Accordingly, a Peruvian study on vulnerable populations and the right to health emphasized systemic inefficiency in providing care that respects the various dimensions of the right to health, as there were delays in the detection, diagnosis and treatment of $\mathrm{TB}^{(23)}$.

The Brazilian Constitution, in its Article 6, emphasizes on "Health as a right of all and duty of the State", with the "guarantee of universal and equal access to health actions and services"(21-22). However, the findings of this study demonstrated the inconsistency of the global goals of TB control and Brazilian legislation on guaranteeing the aforementioned rights, as comprehensive care, social protection and risk reduction of falling ill were not provided.

A study developed in Iran with the objective of understanding the experience of people with TB addressed the importance of protecting the right to privacy, confidentiality and professional secrecy, since this generated concern in people ${ }^{(24)}$. In contrast, this research mentioned the lack of guarantee of the right to protection, dignity and respect from health professionals, who did not fulfill their duty in professional practice, based on respect and advocacy for the rights of people with TB.

Furthermore, data indicate that these professionals are unaware of what TB is and treat people with prejudice and disrespect. On the other hand, studies on the theme of nursing advocacy highlight the defense of health rights as a strategy to reduce inequalities, seeking to achieve the full right of everyone to a healthy life ${ }^{(25-26)}$.

The right to dignity, respect and free coexistence under conditions of equality in the family environment was not guaranteed in the individual sphere of the participants by the families themselves. Based on this, a study points out similar data on the cultural vision of society in relation to TB, showing postures of stigmatization, prejudice, lack of information about the disease, fear and isolation towards these people(27).

Other evidence of a qualitative approach shows the permanence of the stigma associated with TB, involving participants in Bangladesh, Nepal and Pakistan, as something that has a negative impact on social, gender and marriage relations. Women were the most affected and rejected even from the perspective of marriage, where there was prejudice and separation from the spouse ${ }^{(28)}$.

Concerning cases that expose the person with TB to vexing situations that could damage their dignity, it is possible claim damages for the violated right, according to Article 5 of the Brazilian Constitution. These patients are not obligated to disclose information about their disease or treatment to third parties, as those are private and intimate topics, serving as an alert through situations of social discrimination where protection and reparations must be observed ${ }^{(19)}$.

Delay in diagnosing and treating TB in the prison system was part of Marcelo's illness experience, who didn't see his right to health be fully guaranteed. Study data reveal the persistence of the disease in the incarcerated population due to late diagnosis and inadequate treatment, in addition to being a reservoir for TB due to overcrowding ${ }^{(19,29-31)}$.

The Criminal Sentence Administration Act (Lei de Execuções Penais), the Brazilian National Health Plan in the Penitentiary System (Plano Nacional de Saúde no Sistema Penitenciário) and the Brazilian National Council for Criminal and Penitentiary Policy (Conselho Nacional de Política Criminal e Penitenciária) are aimed at constitutionally guaranteeing the rights of those deprived of liberty, including the zeal for health and comprehensive care ${ }^{(19)}$. In this sense, this research reveals findings that go precisely against the recommended standards, as there was a lack of guarantee of the right to health to a vulnerable population that should have their universal access to TB treatment duly provided.

Luis Ricardo, Cleusa, and Maiara announced exercise of labor rights, which ensures leave from work due to illness, under protection of labor laws, and they acknowledged this right because they were ill. Studies have shown that the right to social security and financial protection minimizes suffering and stress for people with TB, generated by fear of unemployment and dismissal from work due to the contagious nature of the disease $e^{(6,8,26)}$.

A study on the rights of people with TB pointed out the economic burden of the disease in the daily lives of those who undergo treatment, as well as the concern with treatment costs 
in realities where it is not free ${ }^{(26)}$. Likewise, data are similar to the findings of this study, where people with greater social vulnerability were those who most felt apprehensive due to economic conditions. Consequently, they are the ones with the greatest need for knowledge and enforcement of their rights.

Luis Ricardo's experience in relation to guaranteeing social security rights was permeated by absence of sickness benefits, denied to him by the INSS medical expert, even when presented with the diagnosis of TB and the visible impairment of his overall state. It is worth saying that this benefit is essential for guaranteeing a dignified life and for the establishment of social well-being ${ }^{(32)}$.

He mentioned his condition of social vulnerability, financial difficulties, not being able to work, in addition to being the only provider of the family. Therefore, in view of this context, it is relevant to mention social incentives such as basic food baskets and transport subsidies, which significantly contribute to treatment compliance, creating bonds, and sometimes they are the only possible means of helping families, like Luis Ricardo's, who face precarious living conditions ${ }^{(33)}$.

Sickness benefit is a social security benefit and it works as an insurance, it is the right of the worker, according to Article 6 of Law 605/49. The insured person shall receive it if he is unable to work for more than 15 consecutive days due to illness. Thus, the first 15 days are paid by the employer and, from that point onwards, Social Security is responsible for payment ${ }^{(19)}$.

It is important to note that active TB is listed by Interministerial Ordinance 2,998/2001 as a disease that is exempt from the need to qualify for the benefit. Assuming that Luis Ricardo was not a formal worker, he would also be entitled to the benefit, even without contributing to Social Security, because due to the nature of the disease, 12-month grace period is exempt ${ }^{(19)}$.

It should be noted that sickness benefits can be requested at the Social Security e-mail address, calling 135 and at the local offices. It is important that people be provided with medical certificates and laboratory exams, required documentation, work permits, payment slips or other documents to certify the activity and length of service, identity document and Natural Persons Register (CPF - Cadastro de Pessos Físicas, the Brazilian individual taxpayer registry identification), registration with Social Integration Program (PIS - Programa de Integração Social, a tax payable by companies to finance insurance for unemployment, child benefits and allowances for low income workers), proof of residence and proof of absence from work filled out by the company ${ }^{(19)}$.

The announcement by the participants about the exercise of rights based on the experiences of living with TB signals that dignity, social, health and other rights need to be strengthened and guaranteed within the State, in families and in society at large. Multisectoral action and the approach to human rights in TB care have been shown to increase the effectiveness and sustainability of disease control actions $s^{(6,19)}$.

\section{Study limitations}

The scarce scientific production on the illness experiences of people with TB limits the data analysis in the comparison of results and their significance. It is suggested to carry out studies on the knowledge of people with TB in relation to their responsibilities according to the Patient's Charter.

\section{Contributions to nursing}

The results have shown the need for nursing professionals to improve care practice that includes instrumentalization on full exercise of rights of people with TB. The aim to improve the health care process in this area includes information and empowerment of people, contributing to improvement of public policies, expanding access of the most vulnerable populations to health services, strengthening the struggle for equity, and fighting disease.

\section{FINAL CONSIDERATIONS}

The study pointed out how people with TB under treatment exercise their rights in the daily experience of illness. It was found that their experiences of living with TB were marked by prejudice, rejection, stigma, and discrimination by the family. Their rights were denied due to the delay in diagnosis and treatment, as well as lack of resolvability in care, delay in diagnosis in the prison system and lack of medication, social security assistance and sickness benefits. They experienced social and economic vulnerability.

The announced rights reflect the situation of social development in the country, characterized by different needs, which require expanding access to health care for the most vulnerable populations. Furthermore, professionals and services need to inform and equip social actors directly or indirectly affected by TB to fully exercise their rights. The State, therefore, must ensure health, respect its Magna Carta, and develop social policies that are effective and that fulfill its health defense responsibilities efficiently and effectively.

The pursuit for the exercise of rights inherent to health demands populational participation. Health professionals/nurses who work with people with TB need to know their rights and guide them so that they are instrumentalized, so these patients can claim them through the effective exercise of social control, exercising their citizenship. May the person be treated by society with dignity and live with others under conditions of equality and respect.

\section{FUNDING}

FAPERGS contributed financial resources to the preparation of the research.

\section{REFERENCES}

1. Nações Unidas Brasil.Centro de Informação das Nações Unidas para o Brasil. Tuberculose provoca uma em cada três mortes relacionadas à AIDS no mundo[Internet]. 2019 [ cited 2019 Jun 17]. Available from: https://nacoesunidas.org/ tuberculose-provoca-uma-em-cada-tres-mortes-relacionadas-a-aids-no-mundo/ 
2. Duarte R, Silva DR, Rendon A, Alves TG, Rabahi MF. Eliminating tuberculosis in Latin America: making it the point. J Bras Pneumol [Internet]. 2018 [cited 2019 Jun 16];44(2):73-6. Available from: http://www.scielo.br/pdf/jbpneu/v44n2/1806-3756-jbpneu-44-02-00073.pdf

3. Assembléia Geral das Nações Unidas. Declaração Universal dos Direitos Humanos [Internet]. Universidade de São Paulo. São Paulo (SP). 1948 [cited 2019 Jul 01]. Available from: http://www.direitoshumanos.usp.br/index.php/Declara\%C3\%A7\%C3\%A3o-Universal-dos-DireitosHumanos/declaracao-universal-dos-direitos-humanos.html

4. Ministério da Saúde (BR). Manual de Recomendações para o Controle da Tuberculose no Brasil [Internet]. Brasília (DF): 2019 [cited 2019 Nov 28]. Available from: http://bvsms.saude.gov.br/bvs/publicacoes/manual_recomendacoes_controle_tuberculose_brasil_2_ed.pdf

5. Barcelos SM, Sousa LGV, Araújo TA. Health in relation to human rights and the Federal Constitution of 1988: the public health system deficiency. luris in mente: Rev Direito Fund Pol Públicas [Internet]. 2016 [cited 2019 Nov 28];1 (1):19-31. Available from: http://www. periodicos.ulbra.br/index.php/iuris/article/view/2266/1587

6. Atif M, Javaid S, Farooqui M, Sarwar MR. Rights and responsibilities of tuberculosis patients, and the global fund: a qualitative study. PLoS ONE [Internet]. 2016 [cited 2019 Jun 17];11(3):e0151321. Available from: https://journals.plos.org/plosone/article/file?id=10.1371/journal. pone.0151321\&type=printable

7. Rivollier É. [Between law and recommendations: what position for the fight against tuberculosis]. Rev Malad Resp [Internet]. 2016 [cited 2019 Jun 20];33(7):639-40. Available from: https://www.em-consulte.com/showarticlefile/1081293/main.pdf. French.

8. Slagle T, Ben YM, Calonge G, Ben AY. Lessons from Africa: developing a global human rights framework for tuberculosis control and prevention. BMC Int Health Hum Rights [Internet]. 2014 [cited 2019 Jun 18];14(1):34. Available from: https://bmcinthealthhumrights. biomedcentral.com/track/pdf/10.1186/s12914-014-0034-7

9. Villas-Bôas ME. [The right and duty of secrecy, as a patient protection]. Rev Bioét [Internet]. 2015 [cited 2019 Jun 21];23(3):511-21. Available from: http://www.scielo.br/pdf/bioet/v23n3/en_1983-8034-bioet-23-3-0513.pdf Portuguese.

10. Moll MF, Mendes AC, Ventura CAA, Mendes IAC. [Nursing care and the exercise of human rights: An analysis based on the reality of Portugal]. Esc Anna Nery [Internet]. 2016 [cited 2019 Jun 21];20(2):236-42. Available from: http://www.scielo.br/pdf/ean/v20n2/en_14148145-ean-20-02-0236.pdf Portuguese.

11. Avila IYC, Escolar JH, Estrada LRA. [Effectiveness of an Educational Program on Childhood Tuberculosis Supported on Information and Communication Technologies Aimed at Community Mothers from Cartagena]. Investig y Educ en Enferm [Internet]. 2016 [cited 2019 Jun 22];34(3):465-73. Available from: http://aprendeenlinea.udea.edu.co/revistas/index.php/iee/article/view/325700/20783042. Spanish

12. Rêgo CCD, Macêdo SM, Andrade CRB, Maia VF, Pinto JTJM, Pinto ESG. [Nurse working process of people with tuberculosis in Primary Health Care]. Rev Baiana Enferm [Internet]. 2015 [cited 2019 Jun 23];29(3):218-28. Available from: https://portalseer.ufba.br/index.php/ enfermagem/article/viewFile/13038/pdf_5 Portuguese.

13. Cavalcante EFO, Silva DMGV. [Nurses' commitment to the care of tuberculosis patients]. Texto Contexto Enferm [Internet]. 2016 [cited 2019 Jun 16];25(3):e3930015. Available from: http://www.scielo.br/pdf/tce/v25n3/pt_0104-0707-tce-25-03-3930015.pdf. Portuguese.

14. Santos JS, Andrade RD, Pina JC, Veríssimo ML, Chiesa AM, Mello DF. Child care and health rights: perspectives of adolescent mothers. Rev Esc Enferm USP [Internet]. 2015 [cited 2019 Jun 20];49(5):732-8. Available from: http://www.scielo.br/pdf/reeusp/v49n5/0080-6234reeusp-49-05-0733.pdf

15. Jung BC. Os significados da experiência do adoecimento de pessoas com tuberculose [Dissertação]. Pelotas: Universidade Federal de Pelotas; 2015.

16. Good BJ. Medicina, racionalidade y experiência: una perspectiva antropológica. Barcelona: Bellaterra, 2003.

17. Rio Grande do Sul (RS). Secretaria da Saúde. Plano Estadual de Saúde 2016-2019. Porto Alegre; 2016.

18. Bardin L. Análise de conteúdo. São Paulo (SP):Edições 70; 2011.

19. Organização Pan-Americana da Saúde. Direitos humanos, cidadania e tuberculose na perspectiva da legislação brasileira [Internet]. 2015 [cited 2019 Nov 28]. Available from: http://iris.paho.org/xmlui/bitstream/handle/123456789/7679/9788579670909_por.pdf;jsessionid=A61 F20AAA92BCC3C660B2AD1CEB6052E?sequence $=1$

20. Dallari SG, Maggio MP. [The legal-political realization of the right to health in the Brazilian Supreme Court: the paradigmatic reference of SL 47-AgR/PE]. Rev Direito Sanitário[Internet]. 2017 [cited 2019 Jun 22];17(3):58-76. Available from: https://www.researchgate.net/ publication/314658328_A_efetivacao_juridico-politica_do_direito_a_saude_no_Supremo_Tribunal_Federal_a_referencia_paradigmatica_ da_SL_47-AGRPE/fulltext/58c41cf6a6fdcce648e4e61f/A-efetivacao-juridico-politica-do-direito-a-saude-no-Supremo-Tribunal-Federal-areferencia-paradigmatica-da-SL-47-AGR-PE.pdf Portuguese.

21. Barreira D. The challenges to eliminating tuberculosis in Brazil. Epidemiol Serv Saúde [Internet]. 2018 [cited 2020 Mar 27];27(1):e00100009. Available from: http://www.scielo.br/pdf/ress/v27n1/2237-9622-ress-27-01-e00100009.pdf Portuguese

22. Congresso Nacional (BR). Constituição 1988: Constituição da República Federativa do Brasil. Brasília, DF: Senado Federal; 1988.

23. Gianella C, Pesantes MA, Ugarte-Gil C, Moore DAJ, Lema C. Vulnerable populations and the right to health: lessons from the Peruvian Amazon around tuberculosis control. Int J Equity Health. 2019;3;18(1):28. doi: 10.1186/s12939-019-0928-z

24. Behzadifar M, Mirzaei M, Behzadifar M, Keshavarzi A, Behzadifar M, Saran M. Patients' experience of tuberculosis treatment using Directly Observed Treatment, Short-Course (DOTS): a qualitative study. Iran Red Crescent Med J [Internet]. 2015 [cited 2019 Jul 2];17(4):e20277. Available from: https://www.ncbi.nlm.nih.gov/pmc/articles/PMC4443395/pdf/ircmj-17-04-20277.pdf 
25. Araújo JL, Freitas RJM, Guedes MVC, Freitas MC, Monteiro ARM, Silva LMS. Brazilian Unified Health System and democracy: nursing in the context of crisis. Rev Bras Enferm [Internet]. 2018 [cited 2019 Jul 1];71(4):2066-71. Available from: http://www.scielo.br/pdf/reben/ v71n4/0034-7167-reben-71-04-2066.pdf

26. Oliveira MAC, Silva TMR. Health advocacy in nursing: contribution to the reorientation of the Brazilian healthcare model. Rev Bras Enferm [Internet]. 2018 [cited 2019 Jul 2];71(Suppl 1):700-3. Available from: http://www.scielo.br/pdf/reben/v71s1/0034-7167-reben-71-s1-0700.pdf

27. Beser A, Bahar Z, Haney MO, Aydogdu NG, Gurkan KP, Arkan G, Cengiz B. Cultural attitudes of society towards tuberculosis patients: a qualitative study. J Pakistan Med Assoc [Internet] 2018 [cited 2020 Mar 27];68(7):1060-1064. Avaialable from: https://pubmed.ncbi.nlm.nih. gov/30317302/

28. Hatherall B, Newell JN, Emmel N, Baral SC, Khan MA."Who Will Marry a Diseased Girl?": marriage, gender, and tuberculosis stigma in Asia. Qual Health Res. 2019;29(8):1109-1119. doi: 10.1177/1049732318812427

29. Sánchez A, Larouzé B. Tuberculosis control in prisons, from research to action: the Rio de Janeiro, Brazil, experience. Cien Saude Colet [Internet]. 2016 [cited 2019 Jun 16];21(7):2071-80. Available from: http://www.scielo.br/pdf/csc/v21n7/en_1413-8123-csc-21-07-2071.pdf

30. Winter BCA, Grazinoli GR. [Tuberculosis in prison: a portrait of the maladies of the Brazilian prison system]. Med Leg Costa Rica [Internet]. 2017 [cited 2019 Jul 6];34(2):20-31. Available from: https://www.scielo.sa.cr/pdf/mlcr/v34n2/1409-0015-mlcr-34-02-20.pdf. Portuguese.

31. Sacramento DS, Gonçalves MJF. Situation of tuberculosis in people deprived of freedom in the period 2007 to 2012. Rev Enferm UFPE. 2017;11(1):140-51. doi: 10.5205/1981-8963-v11i1a11887p140-151-2017

32. Vargas AC, Santos ACT, Souza RM, Silveira-Monteiro CA. Users' perception of a professional rehabilitation service. Rev Bras Saúde Ocup. 2017;42:e11. doi: 10.1590/2317-636900011716

33. Orlandi GM, Pereira ÉG, Biagolini REM, França FOS, Bertolozzi MR. Social incentives for adherence to tuberculosis treatment. Rev Bras Enferm. 2019;16;72(5):1182-8. doi: 10.1590/0034-7167-2017-0654 